\title{
Risk assessment reveals high exposure of sea turtles to marine debris in French Mediterranean and metropolitan Atlantic waters
}

\author{
Darmon Gaëlle ${ }^{1,{ }^{*}}$, Miaud Claude ${ }^{1}$, Claro Françoise ${ }^{2}$, Doremus Ghislain ${ }^{3}$, Galgani Francois ${ }^{4}$
}

${ }^{1}$ UMR 5175 CEFE - CNRS - Université de Montpellier - Université Paul Valéry Montpellier - EPHE, 1919 route de Mende 34283, Montpellier France

${ }_{2}^{2}$ Museum national d'Histoire Naturelle, Service du Patrimoine Naturel, CP41, 57 rue Cuvier, 75005

Paris France

${ }^{3}$ Observatoire PELAGIS, UMS 3462 Université de La Rochelle-CNRS, Pôle Analytique, 5 allée de

I'Océan 17000 La Rochelle France

${ }^{4}$ IFREMER, Immeuble Agostini, ZI Furiani, 20600 Bastia France

*Corresponding author : Gaëlle Darmon, email addresses : darmon gaelle@yahoo.fr ; gaelle.darmon@cefe.cnrs.fr

\begin{abstract}
:
Debris impact on marine wildlife has become a major issue of concern. Mainy species have been identified as being threatened by collision, entanglement or ingestion of debris, generally plastics, which constitute the predominant part of the recorded marine debris. Assessing sensitive areas, where exposure to debris are high, is thus crucial, in particular for sea turtles which have been proposed as sentinels of debris levels for the Marine Strategy Framework Directive and for the Unep-MedPol convention. Our objective here was to assess sea turtle exposure to marine debris in the 3 metropolitan French fronts. Using aerial surveys performed in the Channel, the Atlantic and the Mediterranean regions in winter and summer 2011-2012, we evaluated exposure areas and magnitude in terms of spatial overlap, encounter probability and density of surrounding debris at various spatial scales. Major overlapping areas appeared in the Atlantic and Mediterranean fronts, concerning mostly the leatherback and the loggerhead turtles respectively. The probability for individuals to be in contact with debris (almost $100 \%$ of individuals within a radius of $2 \mathrm{~km}$ ) and the density of debris surrounding individuals (up to 88 items within a radius of $10 \mathrm{~km}$ ) were very high, whatever the considered spatial scale, especially in the Mediterranean region and during the summer season. The comparison of the observed mean debris density with random distribution suggested that turtles selected debris areas. This may occur if both debris and turtles drift to the same areas due to currents, if turtles meet debris accidentally by selecting high food concentration areas, and/or if turtles actively seek debris out, confounding them with their preys. Various factors such as species-specific foraging strategies or oceanic features which condition the passive diffusion of debris, and sea turtles in part, may explain spatio-temporal variations in sensitive areas. Further research on exposure to debris is urgently needed. Empirical data on sea turtles and debris distributions, such as those collected aerially, are essential to better identify the location and the factors determining risks.
\end{abstract}




\section{Introduction}

Ubiquitous, anthropogenic debris are endangering marine ecosystems and the ecological services they provide (Derraik, 2002). Plastics, mostly originating from land-based sources, constitute the predominant part of marine debris (Derraik, 2002, Barnes et al., 2009 and Andrady, 2011). Their resistance and lightness cause them to accumulate and diffuse in the marine environment (Andrady, 2011 and Ryan et al., 2009) and thus to threaten a wide range of taxa (Rochman et al., in press). Many species become entangled or collide with broad items, or ingest fragmented debris, either because they may confuse them with their prey, and/or because they may not discriminate them in their food bowl (Mrosovsky, 1981 and Laist, 1997). Beyond direct mortality, debris more frequently trigger sub-lethal effects related to habitat loss, alteration of movements, decreased absorption of nutrients or disruption of the endocrine system due to consumption of leached toxic substances. All of these impacts may decrease individual chances of survival and reproduction, and possibly disrupt the entire food chain (Derraik, 2002 and Gregory, 2009).

The number of species identified to be impacted by marine debris is increasing: 267 species were listed in 1997 (Laist 1997). Now more than 600 species are known to be affected (Secretariat of the Convention on Biological Diversity and the Scientific and Technical Advisory Panel-GEF, 2012), including marine bird species (van Franeker et al., 2011), fish (Boerger et al., 2010) and cetaceans (de Stefanis et al., 2013). All seven sea turtle species, six of which are listed by the IUCN as threatened (The IUCN Red List of Threatened Species version 2015-4), are also concerned (Schuyler et al., 2014a and Nelms et al., 2015). Entanglement of sea turtles in macro-debris or fishing gear is a major and pressing issue of concern (Gregory, 2009; Wilcox et al., 2013; Vegter et al., 2014 and Nelms et al., 2015). Cases of ingestion have been more widely studied, particularly in the loggerhead turtle Caretta caretta (Nelms et al., 2015). It has been shown that very small pieces of debris can result in the death of individuals (Bugoni et al., 2001 and Santos et al., 2015). Otherwise, debris can accumulate in the digestive tract for several months (Lutz, 1990) and may 
lead to malnutrition, affected buoyancy and diminished swimming capacities, or to other chronic effects depending on the species' foraging strategy or on debris characteristics (Schuyler et al., 2014a and Nelms et al. 2015). These effects decrease turtles' chances to feed, or avoid predators or interactions with anthropogenic activities, and may have potential demographic consequences (Schuyler et al., 2014a and Nelms et al., 2015).

Marine animals which are exposed to floating debris can also be used as environmental sentinels, e.g. in the fulmar Fulmarus glacialis, the digestive content is used as an indicator of regional plastic pollution for the Convention for the Protection of the Marine Environment of the North-East Atlantic (The OSPAR convention), which aims to take all measures to protect the maritime area against pollution in the North-East Atlantic region (van Franeker et al., 2011). The complex life history of sea turtles leads them to use a wide range of habitats and marine compartments during their ontogenetic development, increasing their potential exposure to marine debris (Mansfield and Putman, 2013 and Casale et al., 2007). Being widely distributed in the Mediterranean Sea and the European Atlantic Ocean and being prone to ingest debris, make them possible indicators of debris levels in surface and shallow waters at a large spatial scale. For these reasons, debris ingestion by Caretta caretta, which is higher in the Mediterranean compared to the Atlantic and the Pacific oceans (Tòmas et al., 2002, Dell'Amico and Gambaiani, 2013 and Camedda et al., 2014), was proposed as an indicator of marine debris levels ashore or at sea for monitoring the Good Environmental Status (GES) as defined by the Descriptor 10 ("Marine Litter") of the Marine Strategy Framework Directive (MSFD) (“indicator 10.2.1”, Galgani et al., 2013) and the UnepMedPol convention (“indicator El 18”). In order to establish conservation measures for the protection of sea turtles and consider them as sentinels of their environment, identifying the sensitive areas where sea turtles are exposed to debris and where they thus risk to ingest them or to be entangled, is thus crucial.

Plastic is known to accumulate in ocean gyres, as in the so-called "ocean garbage patches" of the 
Atlantic and Pacific (Moore et al., 2001, Law et al., 2010, Eriksen et al. 2014, Ryan, 2014 and van Sebille et al., in press). Dense human population accentuates pollution in the European waters, and the configuration of the Mediterranean Sea causes this area to be one of the most polluted worldwide (Cózar et al., 2015 and Suaria and Aliani, 2015). Necropsies or observations of the faeces of live individuals performed in the last decade showed inter and intra-regional variations in debris ingestion by sea turtles (Gambaiani and Dell'Amico, 2013, Darmon et al., 2014, Nelms et al., 2015). For example, within the Mediterranean Sea, the occurrence of loggerhead turtles having ingested debris in the North Western Mediterranean area varies from less than $15 \%$ in Sardinia (Camedda et al., 2014) to more than $70 \%$ in Tuscany (Campani et al., 2013) and almost $80 \%$ in Spain (Tòmas et al., 2002). This suggests that the chance to encounter debris is not random and diffuse but rather concentrated in specific high risk areas (i.e. where the probability for sea turtles to be exposed to debris is higher). These high risk areas may be related to regional hydrological characteristics due to the convergence of currents and downwellings. They appear to be preferential foraging areas for sea turtles but also areas in which floating debris accumulate (Witherington et al., 2012 and Cózar et al., 2014). As sea turtles are obligate air-breathers, they most likely occupy the surface waters, where they may actually encounter floating debris.

Our objective here is to assess where sensitive areas are situated and to evaluate the exposure of sea turtles to marine debris in the metropolitan French Mediterranean and Atlantic (the Channel, the Brittany and the Bay of Biscay) waters. Studies aiming to identify hazard areas, where turtles are likely to interact with debris, have recently been highlighted as crucial (Nelms et al., 2015). Such studies are only emerging, possibly because they require combined data, both on animal and debris spatial distributions, which may require heavy technologies for data collection on large spatial scales. Authors have generally used simulation-based approaches established from data on species and debris spatial distributions or debris ingestion found in literature (Schuyler et al., 2015 and Wilcox et al., 2015), but rarely real data. Empirical data collected by ship and aerial surveys may 
yet provide valuable information in order to evaluate and locate sensitive zones, by targeting the areas where turtles and debris spatially overlap. In this study, we explore data collected during the Marine Megafauna Aerial Survey (SAMM) campaign carried out in winter and summer 2011-2012 on the 3 fronts of the French metropolitan maritime domain, during which sea turtles and marine debris were recorded (Pettex et al., 2014). We evaluated (i) debris and sea turtle spatial distributions and overlap, (ii) the probability of sea turtles to be exposed to debris and (iii) the quantity of debris surrounding them at close distances, i.e. where they may be susceptible to be in contact with, and thus ingest, collide or be entangled with debris. Sea turtles may select debris concentration areas, either directly if, for example they confound them with prey (Schuyler et al., 2014b), or indirectly, if debris drift into their displacement routes or are enmeshed within their food (Witherington et al., 2012). In order to examine this hypothesis, we tested (iv) if the observed degree of exposure was similar to a theoretical degree of exposure found with a random distribution of debris.

\section{Material and methods}

\subsection{Study area and data collection}

The study area included the 3 fronts of the metropolitan French Exclusive Economic Zone (the Mediterranean, the Channel and the Atlantic waters), extended to the adjacent waters (the English Channel, the Spanish waters of the South of the Bay of Biscay and the Italian waters in the Pelagos sanctuary). The area covers $559,000 \mathrm{~km}^{2}$ (Figure 1).

Aerial censuses were performed in winter and summer 2011-2012, the first from 3rd November 2011 to $15^{\text {th }}$ February 2012, the second from $15^{\text {th }}$ May to $15^{\text {th }}$ August 2012 . The observations were performed from a Britten Norman twin plane equipped with two side "bubble" windows. Two observers respectively noted the location and number of sea turtles and marine debris among the marine mammals and birds for which the sampling plan was first designed. The data were recorded by a third person on board. The plane flew $183 \mathrm{~m}$ above sea surface at a constant speed of 90 knots, 
along linear transects covering the entire zone. In order to take into account the influence of bathymetry on visibility, the transects were homogeneously distributed in zigzag over 4 strata (Figure 1): the "coastline strata", extending from the coastline to the neritic area, covering 12 nautical miles; the "neritic strata" from the coastline to the $200 \mathrm{~m}$ isobath, corresponding to the continental shelf; the "continental slope strata" from the $200 \mathrm{~m}$ to the $2 \mathrm{~km}$ isobaths; the "oceanic strata" beyond the $2 \mathrm{~km}$ isobath, which includes abyssal plains. Three regions were differentiated: The Channel region, as part of the Greater North Sea, which comprises the entire North front as far as the North sea $\left(92,875 \mathrm{~km}^{2}\right.$, hereafter noted "Channel”), the metropolitan French Atlantic region from Brittany to the South of the Bay of Biscay $\left(282,141 \mathrm{~km}^{2}\right.$, noted "Atlantic") and the Northwestern Mediterranean region including the Gulf of Lion up to the North of Sardinia and the Italian waters in the Pelagos sanctuary $\left(181,377 \mathrm{~km}^{2}\right.$, noted "Mediterranean"). The total length of transect measured $11,629 \mathrm{~km}$ in winter and $10,887 \mathrm{~km}$ in summer on the Channel side, 20,814 $\mathrm{km}$ in winter and $22,977 \mathrm{~km}$ in summer on the Atlantic side, and $13,762 \mathrm{~km}$ in winter and $18,451 \mathrm{~km}$ in summer on the Mediterranean side (Pettex et al., 2014).

Sea turtles were observed following a line transect sampling method, which integrates the distance and the angle of the animal's location from the observer in a $200 \mathrm{~m}$ wide band. Individuals larger than 20-30 cm were potentially detected in the first 2-3 m below the water surface (Gh. D., personal observation). Weather can also affect detection, however sea-state was generally less than 4 Beaufort $(91 \%)$ and subjective conditions estimated "good" for at least one of both sides. Turtles with and without keratinized scut were differentiated between the Cheloniidae and Dermochelyidae families, the first corresponding to the most frequent species in the mainland French waters to the loggerhead turtle Caretta caretta and the green turtle Chelonia mydas (Oliver, 2014), and the second category to the leatherback turtle Dermochelys coriacea. Data on marine debris were collected following a strip transect methodology, in which all objects above $30 \mathrm{~cm}$ in size that were sighted in a $200 \mathrm{~m}$ wide strip on both sides of the plane were recorded. The marine debris were 
differentiated into macrodebris, such as plastics, wooden pallets and various other types of debris (further noted "macrodebris"), and fishing debris which include fishing nets, buoys or boxes for example (further noted "fishing debris"). For each observation, the number of turtle individuals or debris items and their location in decimal degrees were recorded.

\subsection{Statistical analyses}

We considered that the study area was homogeneously sampled, detection was homogeneous in the area, and detection effort was comparable for both marine debris and sea turtles. Because our aim was to explore the interaction of turtles with debris, and not to develop models (e.g. on potentially suitable habitat for turtles), we examined only the "true" locations as noted by observers, for which we converted the coordinates from decimal degrees into metrics (i.e. Lambert 93).

All the analyses were performed separately for each of the 3 regions (Channel, Atlantic, Mediterranean) and for both seasons (winter, summer), by using the software $\mathrm{R}$ version 3.1.0 (R core team 2013), with the libraries adehabitatHR (Calenge et al., 2006), MASS (Venables and Ripley, 2002), rgdal (Keitt et al., 2013) and sp (Pebesma and Bivand, 2005).

\subsubsection{Evaluating spatial distribution of sea turtles, marine debris and their overlap}

We evaluated the marine debris and the sea turtles' spatial distributions using $95 \%$ and $10 \%$ Kernel density estimations. Following Kie (2013), we chose the smoothing parameter $h$ by comparing the shape of the distribution obtained with the ad hoc method (Worton, 1989) with the distributions obtained by decreasing/increasing $h$ progressively by $10 \%$ and selected it visually. The value of $h$ which fitted the data best corresponded to the most uniform distribution, without fragmentation. In order to evaluate the probability of debris occurrence in the areas occupied by the turtles, the overlap was estimated between the marine debris and the sea turtles' distributions as the volume under the debris 95\% Kernel utilization distribution that was inside the turtle 95\% Kernel 
utilization distribution.

\subsubsection{Quantifying exposure of sea turtles to marine debris}

\subsubsection{Evaluating exposure level of sea turtles to marine debris}

In order to evaluate the degree of exposure of sea turtles to marine debris at various spatial scales, we calculated the linear distance between each turtle and each debris location. We calculated the number of locations in distance classes from each turtle, from $50 \mathrm{~m}$ to $10 \mathrm{~km}$ every $50 \mathrm{~m}$, which we multiplied by the number of debris items observed at the corresponding debris locations in order to take into account the actual abundance of debris observed around the turtle. Based on this result, we calculated (i) the frequency of turtles being surrounded by debris by counting the number of turtles with debris out of the total number of turtles at each distance class considered, and (ii) the mean number of surrounding debris per turtle for each distance class.

\subsubsection{Testing sea turtles' selection for marine debris areas}

To assess whether the observed quantity of debris surrounding turtles may have occurred by chance or identify if, on the contrary, turtles may avoid/select areas with debris, we tested if the observed exposure was similar to what would be obtained with a random distribution of marine debris. We constructed a null distribution by randomizing the same number of debris locations and assigning the observed abundances to them randomly, while leaving the turtles' locations fixed. We repeated this procedure 100 times. We subsequently calculated the mean exposure of turtles to the randomized debris per distance class, in the same way as presented here-above.

To evaluate the magnitude of the difference between the observed and the theoretical exposure acquired with the 100 random distributions of debris, we calculated, for each distance class, the Cohen's d standardized effect sizes, expressed in standard deviation unit. These values were obtained with the ratios of the difference between the observed mean number of debris per turtle and the theoretical mean number of debris per turtle under the null hypothesis, over the standard 
deviation of the combined groups. Therefore, for example, a d value superior to 0 indicates that observed densities of debris surrounding turtles are superior to what would be observed by chance, and inversely. We then evaluated if the observed mean number of surrounding debris per turtle did not differ from what would have been seen by chance alone by calculating, for each distance class, the probability that the observed exposure was superior to the random exposure. This probability corresponded to the mean number of times the observed number of surrounding debris per turtle was superior to the mean number of randomized debris per turtle.

\subsubsection{Assessing the influence of species, type of debris and region on exposure}

Finally, we evaluated the influence of region, species and type of debris on the mean number of debris per turtle. Because of the distribution of recorded data (Table 1, e.g., absence of Dermochelyidae turtle in the Mediterranean region or most of the observations of turtles recorded in Summer), we did not combine all these variables in a complete model. We rather tested the difference in the $\log +1$ transformed mean number of debris per turtle in a radius of $10 \mathrm{~km} \mathrm{I}$ ) between turtle families (Cheloniidae and Dermochelyidae) using a Student's t test, ii) between species in interaction with type of debris (fishing debris and macrodebris) and iii) between regions (Channel, Atlantic and Mediterranean regions) in interaction with the type of debris, using analyses of variances.

\section{Results}

\subsection{Summary of the collected data}

Among the 27,907 recorded locations (7,950 observations in winter and 19,957 in summer), 469 were locations with at least 1 turtle (382 Cheloniidae $(81.45 \%$ of turtle locations) and 87 Dermochelyidae $(18.55 \%)$ ) and 27,438 were locations with at least 1 item of debris (710 items of fishing debris, that is $2.59 \%$ of debris locations, and 26,728 items of macrodebris $(97.41 \%)$. Most of turtles were recorded in summer, essentially Cheloniidae in the Mediterranean (332 individuals 
in summer) and Dermochelyidae in the Atlantic (74 individuals in summer), and all locations corresponded generally to 1 individual (Table 1A). There are also many more debris in summer compared to winter. Although there were more fishing debris in the Channel region compared to the two other regions in summer, most of the debris were macrodebris and were recorded in the Atlantic and the Mediterranean regions, which, relatively to the prospected surface $(65 \%$ smaller than Atlantic), constituted the most polluted area (Table 1B).

\subsection{Spatial distribution of sea turtles, marine debris and their overlap}

Whatever the region and the season, the value of $h$ obtained with the ad hoc method was the one which fitted the best both the debris and the turtles' spatial distributions (values given in Table 2). The average spatial distributions (Kernel 95\%) of debris and sea turtles covered almost all the study area, over more than $200,000 \mathrm{~km}^{2}$ in the Mediterranean and the Atlantic regions during both seasons (Table 2, Figure 2). The sea turtle distribution varied substantially between winter and summer, going further North in the Atlantic and further South in the Mediterranean in summer. In the Atlantic regions, turtles were concentrated opposite to the Gironde estuary and further offshore in the ocean in winter, and reached the tip of Brittany and its North coast (Channel) in summer. In the Mediterranean region, the sea turtle core area was situated in the North-Eastern coast of Corsica, extended towards the Balearic Islands in winter. In summer, they went down between the Balearic Island and Sardinia.

The marine debris distribution was globally dispersed over the whole area but mostly concentrated in the Normandy coast in the Channel region, across the Gironde estuary to the Basque and the Cantabrian coasts in the Atlantic, and particularly from the Languedoc coast to the area between Sardinia and the Balearic Islands in the Mediterranean. Other patches, variable in size, appeared in the Channel and in the Mediterranean regions, such as an important zone located at the North-Eastern Corsica. The greatest overlaps between sea turtles and marine debris therefore 
appeared in the centre of the Bay of Biscay, opposite the Gironde estuary both in winter and in summer in the Atlantic, and between the Balearic Islands and Sardinia in the Mediterranean, with another smaller overlapping area at the North-East of Corsica in summer (Figure 2).

\subsection{Levels of turtle exposure to debris}

\subsubsection{High probability of encounter between turtles and debris}

The probability of spatial interaction between debris and turtles was high in all regions and stronger during summer. The probability to find debris in turtle spatial distribution (Kernel 95\%) was 0.89 in summer and 0.71 in winter in the Mediterranean region, 0.71 in summer and 0.7 in winter in the Atlantic region, 0.93 in summer in the Channel region (as no turtle was observed in the Channel region in winter, no interaction with debris was recorded). Inversely, the probability to find a turtle in debris spatial distribution was 0.93 in summer and 0.96 in winter in the Mediterranean region, 0.95 in summer and 0.66 in winter in the Atlantic, and 0.24 in summer in the Channel region (Table 2).

\subsubsection{Exposure levels}

\subsubsection{High probability that individuals have debris around them}

The frequency of individuals surrounded by debris varied from 0 to almost $100 \%$ depending on the region, the season and the distance (Figure 3) (from 5.86\% at $50 \mathrm{~m}$ to $99.07 \%$ at $10 \mathrm{~km}$ in the Mediterranean region; from 8.11 to $98.65 \%$ in the Atlantic region; from 0 to $100 \%$ in the Channel region, in summer; from 7.84 to $94.12 \%$ in the Mediterranean region and 0 to $100 \%$ in the Atlantic region, in winter). A plateau started to be reached around about $2 \mathrm{~km}$ (Figure 3). At this distance, $90.43 \%$ of turtles were exposed to debris in summer and $66.67 \%$ in winter in the Mediterranean region, $87.83 \%$ in summer and $62.65 \%$ in winter in the Atlantic region and $91.67 \%$ in summer in the Channel region (Table 2). 


\subsubsection{High density of debris surrounding turtle individuals}

The observed mean number of items of debris increased globally constantly without saturation up to the maximum evaluated distance $(10 \mathrm{~km})$, regardless of the season or the region (Figure 3). The number of debris items surrounding turtles was very high in summer compared to winter, particularly in the Mediterranean region. The mean observed number of debris items per turtle reached 88.48 in the Mediterranean region in summer (with a minimum of 0.12 on average at a radius of $50 \mathrm{~m}$ ) and 29.1 (minimum 0.23 at $50 \mathrm{~m}$ ) in winter. In the Atlantic region, turtles had 0.12 (at $50 \mathrm{~m}$ ) to 45.19 items of debris at $10 \mathrm{~km}$ on average in summer, and 0 to 4.62 in winter. In the Channel region (summer), they had 0 to 18.42 items of debris at $50 \mathrm{~m}$ and $10 \mathrm{~km}$ respectively.

\subsubsection{Higher exposure than expected by chance}

Turtles were more exposed to debris than expected by chance alone at all the tested distances (Appendix 1). The probability of the mean observed exposure to debris being greater than the simulated mean exposure calculated exceeded 0.5 at a distance of nearly $2 \mathrm{~km}$, except in the Channel region (summer), where it was around $6 \mathrm{~km}$ (Appendix 1). The small Cohen's d values obtained at the considered distances were low, maybe because of the big number of debris data which increased the standard deviation. However, the $d$ values were always superior to 0 . The mean number of debris items observed per turtle was thus always higher than what would be observed with a random distribution of debris, except in the Mediterranean region in winter, where it surpassed the random distribution only after $6 \mathrm{~km}$ (Figure 4). The Cohen's d values increased with distance, with a saturation around $2 \mathrm{~km}, 4 \mathrm{~km}$ and $6 \mathrm{~km}$ from turtles depending on the region and the season (Appendix 2).

\subsubsection{Exposure to debris varies according to species, type of debris and region}

Exposure depended both on the region and on the type of debris $(F=35,93, p<<0,01)$, turtles being more exposed to debris in the Mediterranean (40,2 $\pm 80,24$ items within a $10 \mathrm{~km}$ radius) than in the two other regions (respectively $20,77 \pm 40,07$ and $9,21 \pm 13,48$ items in the Atlantic and the 
Channel regions) and much more to macrodebris than to fishing debris (respectively 71,74 $\pm 91,98$ items and $0.28 \pm 0.73$ items on average around a turtle). Considering a $10 \mathrm{~km}$ radius around each individual, the Cheloniidae were exposed to as many items than the Dermochelyidae turtles (39.69 \pm 79.63 and $19.87 \pm 39.0$ debris items; $\mathrm{t}=1.2793, \mathrm{p}=0.2$ on transformed data), but the first were significantly more exposed to macrodebris than fishing debris compared to the second $(79.2 \pm 97,8$ and $38,9 \pm 48,24$ items respectively, $\mathrm{t}=5,53, \mathrm{p}<<0,01)$.

\section{Discussion}

\subsection{Assessing sensitive areas from aerial surveys}

Our results showed that aerial surveys provide valuable data to assess sensitive areas where sea turtles are exposed to marine debris. The collected data are indeed consistent with the data recorded from sea turtle stranding networks over the same study period. These networks observed mostly the same species, Dermochelyidae (leatherbacks) in the Atlantic front ( $>75 \%$, data from R.T.M.A.E. stranding network and the C.E.S.T.M. rescue centre) and Cheloniidae, which appear to be mainly loggerheads in the Mediterranean front (96.6\%, R.T.M.M.F. sea turtle network and the CestMed rescue centre (Claro and Hubert, 2011 and Dell'Amico and Gambaiani, 2013), as confirmed by historical bycatches and stranding data over 15 years (Oliver, 2014). They recorded individual sizes almost consistent with the minimum size observed from the plane $(20-30 \mathrm{~cm})$ : the straight carapace length of the recovered leatherback individuals measured $100 \mathrm{~cm}$ minimum $(\mathrm{n}=25)$ and $17.5 \mathrm{~cm}$ for loggerheads $(n=3)$ in the Atlantic front, and respectively $140 \mathrm{~cm}(\mathrm{n}=2)$ and $26.6 \mathrm{~cm}(\mathrm{n}=65)$ in the Mediterranean front (Dell'Amico and Gambaiani, 2013).

The collected data also highlight and attest to high pollution levels recorded in the studied waters, especially in the Mediterranean region (Cózar et al. 2015, Suaria and Aliani, 2015, Galgani et al., 2000 and Galagni, 2015). The sailing boat surveys carried out by the NGO EcoOcean Institut in 2006-2008 in the eastern part of the Gulf of Lion showed most of the debris were plastic bags, 
plastic bottles, plastic jugs, polystyrene and micro-plastics (EcoOcean Institut, unpublished results).

Plastics are therefore the predominant part of debris found in all marine environments, up to

80\%(Derraik, 2002, Barnes et al., 2009, Andrady, 2011 and Depledge et al., 2013).

\subsection{Exposure of sea turtles to marine debris}

\subsubsection{Spatio-temporal variations in sea turtle and marine debris distributions}

The recorded data shows spatio-temporal variations in sea turtle and marine debris abundance and spatial distributions, which underlines two different processes that affect the variations in size, space and time of the sensitive areas.

Overall, the zones located in front of the Gironde estuary and up to the Channel region on the Atlantic side, and from the North-Eastern coast of Corsica towards the area between the Balearic Island and Sardinia in the Mediterranean, constitute preferential occupation areas for sea turtles. However, their distribution varies substantially between the two observation seasons and it was found that fewer turtles occupied the study regions in winter (Table 1A and Figure 2). This may be due to variations in oceanic conditions such as temperature, to which Cheloniid turtles are sensitive (Mansfield and Putman, 2013), and to variations in the currents which influence the displacement of turtles and their food (Mansfield et al., 2014 and Witherington et al., 2012).

The presence of debris also varied seasonally, however much more in abundance than in spatial distribution (Table 1B and Figure 2). Debris were quite widely disseminated, yet especially concentrated from the Gironde estuary to the South, between the French and Spanish coasts, in the Atlantic region. In the Mediterranean region, accumulation areas form in the Gulf of Lion between Sardinia and the Balearic Islands, and in a patch situated in the North-East of Corsica. Furthermore, debris concentration appeared close to the Gironde and the Rhône estuaries, suggesting that river outflows may play a role, by transporting and pushing away the debris.

\subsubsection{Overlapping areas with high exposure rates at the inter and intra-regional scales}


The major sensitive areas, where sea turtles are highly exposed to marine debris, appeared at the regional level, principally one in the Atlantic front, at the centre of the Bay of Biscay, and two in the Mediterranean front, North of Corsica, and between Sardinia and the Balearic Islands. The degree of exposure was very high in the 3 metropolitan French fronts as the perceived probability for turtles to encounter debris (i.e. the probability that debris are located in sea turtle distribution ranges) was at least 0.7 in the Atlantic and around 0.9 in the Channel and the Mediterranean waters. The location and magnitude of overlapping areas likely depend primarily on environmental features, which influence both debris and turtles' food passive diffusion, such as the major currents (Collignon, et al., 2012 and Galgani, et al., 2013). Simulations of debris flows highlight an accumulation zone during a few weeks or months close to the Ligurian- Provencal current in the Mediterranean (Mansui et al., 2015), where a high overlapping area was found.

\subsubsection{High exposure levels at the fine spatial scale}

The frequency of turtles surrounded by debris increased consistently with the considered radius. However, already 5 to $10 \%$ of turtles were likely to be in contact with debris at a distance of $50 \mathrm{~m}$, and nearly $100 \%$ were exposed to debris within a radius of only $2 \mathrm{~km}$ around them, highlighting that a high exposure already appear at a very small spatial scale. Within a radius of $10 \mathrm{~km}$, which turtles can easily cover in a few hours (Bentivegna, 2002), individuals had more than 5 observed debris around them in the Atlantic zone and more than 88 in the Mediterranean. This observed density was superior to a theoretical random debris density below $10 \mathrm{~km}$, indicating that turtles select debris areas. Turtles may encounter debris in the convergence current areas either because they are swept away among the passive organisms and debris, or because they actively select these areas where the plankton productivity increases and in which debris also accumulate (Witherington et al., 2012 and Mansui et al. 2015).

\subsubsection{Seasonal variations in exposure to debris}

The exposure of sea turtles to debris vary seasonally, greatly increasing in size, location and 
intensity during summer compared to winter. During this period, the number of both turtles and debris rises considerably (Table 1). Sea turtles probably follow the warmer waters, while booming human activities related to fishing and tourism increase debris discharges. Indeed, our results show very high debris concentrations in summer, with patches up to 200 items per location in the Atlantic and Channel regions and up to 250 items in the Mediterranean.

\subsubsection{Difference between species in exposure to debris and associated risks}

Exposure levels are related to species abundance and local debris concentrations. Our results highlight that the loggerhead turtle is more exposed to macrodebris in the Mediterranean than the leatherback turtle in the Atlantic, but it has been shown that they are both very likely to ingest debris (Schuyler et al., 2014 and Nelms et al., 2015). The loggerhead turtle, as a generalist feeder, may be more prone to ingest debris compared to other species (Bugoni et al., 2001; Tòmas et al., 2001, 2002 and Hoarau et al., 2014), but the jellyfish, a highly preferred prey for leatherbacks, may be easily confounded with plastic bags (Mrosovsky et al., 2009, Camedda et al., 2014 and Schuyler et al., 2014b). Necropsies and the observations of faeces during the study period confirmed high ingestion rates both in the Atlantic front where $57.1 \%$ of leatherbacks $(n=7)$ had ingested debris and in the Mediterranean front, where no debris was found in 2 necropsied loggerhead turtles, but 11 out of 54 individuals (20.4\%) excreted debris (Dell'Amico and Gambaiani, 2013). These debris were mostly soft plastics, nylon, lollipop sticks and other kinds of plastics, from a few to several tens of centimetres (Dell'Amico and Gambaiani, 2013).

\subsection{An urgent need for further research}

As exposure levels are highly correlated with entanglement and ingestion risks (Wilcox et al., 2013 and Schuyler et al., 2015), the very high exposures of sea turtles to the marine debris observed in the 3 metropolitan French fronts thus involve high danger of contact, entanglement or ingestion. Moreover, plastic does not degrade but becomes fragmented and persists in the marine environment 
from decades to centuries, increasing the risk of entanglement or ingestion by marine organisms in time and magnitude (Moore et al., 2001). The aerial surveys done by the naked eye at $183 \mathrm{~m}$ above the sea surface definitively allow the discernment of debris larger than $30 \mathrm{~cm}$, but much smaller debris are obviously also present. Pollution by micro-plastics $(<5 \mathrm{~mm})$ can range from hundreds to hundreds of thousands per square kilometre (Galgani, 2015). Debris ingestion or entanglement with debris is thus likely to increase in the overlapping areas. As stated in Nelms et al. (2015)'s call for research, investing in research on spatial overlapping areas with debris is crucial, while plastics levels and impacts are constantly increasing (Wilcox et al., 2015). Added to the high risks for sea turtle survival caused by accidental captures (Casale et al., 2010), plastics are another threat which is not yet fully documented. It has thus become essential to better identify the areas and intensity of exposure to debris of turtles as well as other marine wildlife.

Aerial surveys are useful to prospect very large spatial scales, even if detection partly depends on factors such as the size, colour and depth of the observed objects. Collecting other data aerially would also be necessary to assess if overlapping areas and the magnitude of exposure to debris are stable and/or if other sensitive areas exist. This approach may be used in other marine regions of the globe to better identify the factors increasing the risks for turtles to be exposed to floating debris. For this purpose, developing citizen participatory programs and working with professional on-board observers in ferries (Arcangeli et al., 2010) or sailing ships (EcoOcean Institut, pers. comm.) may provide low-cost systematic surveys. Tracking turtles using satellites tags equipped with diving sensors is also important to better describe vertical overlaps with debris (Nelms et al., 2015).

Combined with simulation models, the empirical collected data could then better allow to account for spatio-temporal variability in sensitive areas, and test both turtle-specific and environmental-specific factors. The differences between oceans and seas, e.g. the influence of tide, may influence the probability of encounter between turtles and debris, and should also be assessed. The Mediterranean, an almost closed sea, is probably one of the most polluted areas by debris, as 
much in surface as on the sea floor (Galgani et al., 2000 and Galgani, 2015). Accurate data and finer simulations should better assess exposure to debris and their impacts in this area, to which particular attention should be paid through further research.

\section{Acknowledgements}

We wish to express our deepest thanks to the staff members of the SAMM campaign for sharing their data, Matthieu Authier and Mélanie Racine for most useful discussions and for providing us with Figure 1. We are also very grateful to our colleagues for their useful comments, supports or advice, and in particular Clément Calenge, Jean-Yves Banargaud, Sabrina Servanty, Mathieu Basille, Simon Benhamou, EcoOcean Institut (Léa David and Nathalie Di-Méglio), and Adeline Darlington for her help with English. We would also like to thank the French rescue centres, the C.E.S.T.M. Aquarium La Rochelle (Florence Dell'Amico) and the CestMed (Delphine Gambaiani and Jean-Baptiste Senegas), the R.T.M.M.F. (Guy Oliver and Jacques Sacchi) for valuable discussions and their considerable effort to protect sea turtles. Finally, we wish to express our gratitude to the French Ministry of Ecology for their funding which enabled the aerial surveys and this study.

\section{References}

Andrady, A.L., 2011. Microplastics in the marine environment. Marine Pollution Bulletin 62, 15961605. doi:10.1016/j.marpolbul.2011.05.030

Arcangeli, A., Muzi, E., Tepsich, P., Carcassi, S., Castelli, A., Crosti, R ., Di Vincenzo, M ., Magliozzi, C., Marini, L., Poggi, A., Poldi, A., Pulcini, M., Ricci, S., Safontas, C., Sdringola, S., Ukmar, E., 2010. Large scale cetacean monitoring from passenger ferries in Italy. Networking summer 2008 surveys. In Proceedings of the twenty-third annual conference of the European Cetacean Society Istanbul, Turkey. 2-4 March 2009. Eds Pierce, G.J. and Lick., R. 
Barnes, D.K.A., Galgani, F., Thompson, R.C., Barlaz, M., 2009. Accumulation and fragmentation of plastic debris in global environments. Philosophical Transaction of the Royal Society B 364, 1985-1998. doi:10.1098/rstb.2008.0205

Bentivegna, F., 2002. Intra-Mediterranean migrations of loggerhead sea turtles (Caretta caretta) monitored by satellite telemetry. Marine Biology 141, 795-800. doi:10.1007/s00227-002-0856-Z

Boerger, C.M., Lattin, G.L., Moore, S.L., Moore, C.J., 2010. Plastic ingestion by planktivorous fishes in the North Pacific Central Gyre. Marine Pollution Bulletin 60, 2275-2278. doi:10.1016/j.marpolbul.2010.08.007

Bugoni, L., Krause, L., Petry, M.V., 2001. Marine debris and human impacts on sea turtles in southern Brazil. Marine Pollution Bulletin 42, 1330-1334.

Calenge, C. 2006. The package adehabitat for the R software: a tool for the analysis of space and habitat use by animals Ecological Modelling 197, 516-519.

Camedda, A., Marra, S., Matiddi, M., Massaro, G., Coppa, S., Perilli, A., Ruiu, A., Briguglio, P., de Lucia, G.A., 2014. Interaction between loggerhead sea turtles (Caretta caretta) and marine litter in Sardinia (Western Mediterranean Sea). Marine Environmental Research 100, 25-32. doi:10.1016/j.marenvres.2013.12.004

Campani, T., Baini, M., Giannetti, M., Cancelli, F., Mancusi, C., Serena, F., Marsili, L., Casini ,S., Fossi, M.C., 2013. Presence of plastic debris in loggerhead turtle stranded along the Tuscany coasts of the Pelagos Sanctuary for Mediterranean Marine Mammals (Italy). Marine Pollution Bulletin 74, 225-230.

Casale, P., Cattarino, L., Freggi, D., Rocco, M., Argano, R., 2007. Incidental catch of marine turtles by Italian trawlers and longliners in the central Mediterranean. Aquatic Conservation: Marine and Freshwater Ecosystems 17, 686-701. doi:10.1002/aqc.841

Claro, F. and Hubert, P. 2011. Impact des macrodéchets sur les tortues marines en France métropolitaine et d'Outre-mer. MNHN-SPN, Paris, 51p 
Collignon, A., Hecq, J.H., Glagani F., Voisin P., Collard F., Goffart, A. 2012. Neustonic microplastic and zooplankton in the North Western Mediterranean Sea. Marine Pollution Bulletin 64, 861864. doi:10.1016/j.marpolbul.2012.01.011.

Cózar, A., Sanz-Martín, M., Martí, E., González-Gordillo, J.I., Ubeda, B., Gálvez, J.Á., Irigoien, X., Duarte, C.M., 2015. Plastic Accumulation in the Mediterranean Sea. PLoS ONE 10, e0121762. doi:10.1371/journal.pone.0121762

Darmon, G., Miaud, C., Claro, F., Gambaiani, D., Dell'Amico, F., Galgani, F, 2014. Pertinence des tortues caouannes comme indicateur de densité de déchets en Méditerranée Dans le cadre de la Directive Cadre Stratégie pour le Milieu Marin (indicateur 2.1 du descripteur n 10 ), 29 pp.

Dell'Amico F., Gambaiani D., 2013. Bases scientifiques et techniques en vue de l'elaboration d'un objectif de qualite environnementale pour l'impact des dechets sur les tortues marines en Europe. $53 \mathrm{p}$.

Depledge, M.H., Galgani, F., Panti, C., Caliani, I., Casini, S., Fossi, M.C. 2013., Plastic litter in the sea. Marine Environmental Research 92 : 279-281. doi:10.1016/j.marenvres.2013.10.002

Derraik, J.G.B., 2002. The pollution of the marine environment by plastic debris: a review. Marine Pollution Bulletin 44, 842-852. doi:10.1016/S0025-326X(02)00220-5

de Stephanis, R., Giménez, J., Carpinelli, E., Gutierrez-Exposito, C., Cañadas, A., 2013. As main meal for sperm whales: Plastics debris. Marine Pollution Bulletin 69, 206-214.

doi:10.1016/j.marpolbul.2013.01.033

Eriksen, M., Lebreton, L.C.M., Carson, H.S., Thiel, M., Moore, C.J., Borerro, J.C., Galgani, F., Ryan, P.G., Reisser, J., 2014. Plastic Pollution in the World's Oceans: More than 5 Trillion Plastic Pieces Weighing over 250,000 Tons Afloat at Sea. PLoS ONE 9, e111913. doi:10.1371/journal.pone.0111913

Galgani, F., Leaute, J.P., Moguedet, P., Souplet, A., Verin, Y., Carpentier, A., Goraguer, H., Latrouite, D., Andral, B., Cadiou, Y., Mahe, J.C., Poulard, J.C., Nerisson, P., 2000. Litter on the 
Sea Floor Along European Coasts. Marine Pollution Bulletin 40, 516-527. doi:10.1016/S0025326X(99)00234-9

Galgani, Francois, Hanke, G., Werner, S., De Vrees, L. 2013. Marine Litter within the European Marine Strategy Framework Directive. http://archimer.ifremer.fr/doc/00155/26586/24792.pdf

Galgani, F., 2015. Marine Litter Within the European Marine Strategy Framework Directive, in:

Ceccaldi, H.-J., Hénocque, Y., Koike, Y., Komatsu, T., Stora, G., Tusseau-Vuillemin, M.-H. (Eds.), Marine Productivity: Perturbations and Resilience of Socio-Ecosystems. Springer International Publishing, pp. 93-100.

Goldstein M, Carson H, Eriksen M (2014) Relationship of diversity and habitat area in North Pacific plastic-associated rafting communities. Marine Biology Doi:10.1007/s00227-014-2432-8.

Gregory, M.R. 2009. Environmental implications of plastic debris in marine settingsentanglement, ingestion, smothering, hangers-on, hitch-hiking and alien invasions. Philosophical Transactions of the Royal Society B 364, 2013-2025. doi:10.1098/rstb.2008.0265

Hoarau, L., Ainley, L., Jean, C., Ciccione, S., 2014. Ingestion and defecation of marine debris by loggerhead sea turtles, Caretta caretta, from by-catches in the South-West Indian Ocean. Marine Pollution Bulletin 84, 90-96. doi:10.1016/j.marpolbul.2014.05.031

Keitt TH, Bivand R, Pebesma E, Rowlingson B (2013). rgdal: Bindings for the Geospatial Data Abstraction Library R package version 0.8-3, URL: http://CRAN.R-project.org/package=rgdal.

Kie, J.G., 2013. A rule-based ad hoc method for selecting a bandwidth in kernel home-range analyses. Anim Biotelemetry 1, 1-12. doi:10.1186/2050-3385-1-13

Laist, D. 1987. Overview of the biological effects of lost and discarded plastic debris in the marine environment. Marine Pollution Bulletin 18 : 319 - 326.

Law, K.L., Morét-Ferguson, S., Maximenko, N.A., Proskurowski, G., Peacock, E.E., Hafner, J., Reddy, C.M., 2010. Plastic Accumulation in the North Atlantic Subtropical Gyre. Science 329, 1185-1188. doi:10.1126/science.1192321 
Lutz, P. L. 1990. Studies on the ingestion of plastic and latex by sea turtles. In Proceedings of the Workshop on the Fate and Impact of Marine Debris, Honolulu, pp. 719-735.Mrosovsky, N. 1981. Plastic jellyfish. Marine Turtle Newsletter $17: 5-7$.

Mansfield, K.M., and N.F. Putman. 2013. Oceanic habits and habitats - Caretta caretta. Pp. 189205 In Biology of Sea Turtles, Vol. 3. Wyneken, J., K.J. Lohmann, and J.A. Musick (Eds.). CRC Press, Boca Raton, Florida, USA.

Mansfield, K.L., Wyneken, J., Porter, W.P., Luo, J., 2014. First satellite tracks of neonate sea turtles redefine the "lost years" oceanic niche. Proceedings of the Royal Society of London B: Biological Sciences 281, 20133039. doi:10.1098/rspb.2013.3039

Mansui, J., Molcard, A., Ourmières, Y., 2015. Modelling the transport and accumulation of floating marine debris in the Mediterranean basin. Marine Pollution Bulletin 91, 249-257. doi:10.1016/j.marpolbul.2014.11.037

Moore, C.J., Moore, S.L., Leecaster, M.K., Weisberg, S.B., 2001. A Comparison of Plastic and Plankton in the North Pacific Central Gyre. Marine Pollution Bulletin 42, 1297-1300. doi:10.1016/S0025-326X(01)00114-X

Nelms, S.E., Duncan, E.M., Broderick, A.C., Galloway, T.S., Godfrey, M.H., Hamann, M., Lindeque, P.K., Godley, B.J., 2015. Plastic and marine turtles: a review and call for research. ICES J. Mar. Sci. fsv165. doi:10.1093/icesjms/fsv165

Oliver G., 2014. Données historiques et nouvelles observations concernant les tortues marines (Reptilia, Chelonii) sur les côtes françaises de Méditerranée (1996-2010) Bulletin de la Société Herpétologique de France 149, 25-57.

Pebesma, E.J., Bivand, R.S., 2005. “Classes and methods for spatial data in R.” R news 5 (2), 9-13

Pettex, E., Lambert, C., Laran, S., Ricart, A., Virgili, A., Falchetto, H., Authier, M., Monestiez, P., Van Canneyt, O., Dorémus, G., Blanck, A., Toison, V., Ridoux, V., 2014. Suivi Aérien de la Mégafaune Marine en France métropolitaine. SAMM 1 et 2 -Hiver 2011/2012 et Eté 2012. 
Rapport final Observatoire PELAGIS réalisé dans le cadre du Programme d'Acquisition de Connaissances sur les Oiseaux et les Mammifères Marins -PACOMM. 169 p ; $\mathrm{ftp} / / / \mathrm{ftpaamp}$.airesmarines.fr/PACOMM/Volet1_SAMM/Rapport/SAMM_rapport_final_13112014.pd

Rochman, C.M., Browne, M.A., Underwood, A.J., van Franeker, J.A., Thompson, R.C., AmaralZettler, L.A., in press. The ecological impacts of marine debris: unraveling the demonstrated evidence from what is perceived. Ecology. doi:10.1890/14-2070.1

Ryan, P. G., Moore, C. J., van Franeker, J. A., \& Moloney, C. L. 2009. Monitoring the abundance of plastic debris in the marine environment. Philosophical Transactions of the Royal Society B: Biological Sciences 364, 1999-2012.

Ryan, P.G., 2014. Litter survey detects the South Atlantic "garbage patch." Marine Pollution Bulletin 79, 220-224. doi:10.1016/j.marpolbul.2013.12.010

Santos, R.G., Andrades, R., Boldrini, M.A., Martins, A.S., n.d. Debris ingestion by juvenile marine turtles: An underestimated problem. Marine Pollution Bulletin. doi:10.1016/j.marpolbul.2015.02.022

Schuyler, Q., Hardesty, B.D., Wilcox, C., Townsend, K., 2014a. Global Analysis of Anthropogenic Debris Ingestion by Sea Turtles. Conservation Biology 28 :129-139. doi:10.1111/cobi.12126

Schuyler, Q.A., Wilcox, C., Townsend, K., Hardesty, B.D., Marshall, N.J., 2014b. Mistaken identity? Visual similarities of marine debris to natural prey items of sea turtles. BMC Ecology 14, 14. doi:10.1186/1472-6785-14-14

Schuyler, Q.A., Wilcox, C., Townsend, K.A., Wedemeyer-Strombel, K.R., Balazs, G., van Sebille, E., Hardesty, B.D., 2015. Risk analysis reveals global hotspots for marine debris ingestion by sea turtles. Glob Chang Biol. doi:10.1111/gcb.13078

Secretariat of the Convention on Biological Diversity and the Scientific and Technical Advisory Panel-GEF. 2012. Impacts of Marine Debris on Biodiversity: Current Status and Potential 
Solutions, Montreal, Technical Series 67, 61pp.

Suaria, G., Aliani, S., 2014. Floating debris in the Mediterranean Sea. Mar. Pollut. Bull. 86, 494504. doi:10.1016/j.marpolbul.2014.06.025

Tòmas, J., Aznar, F.J., Raga, J.A., 2001. Feeding ecology of the loggerhead turtle Caretta caretta in the western Mediterranean. Journal of Zoology 255, 525-532. doi:10.1017/S0952836901001613

Tòmas, J., Guitart, R., Mateo, R., \& Raga, J. A. 2002. Marine debris ingestion in loggerhead sea turtles, Caretta caretta, from the Western Mediterranean. Marine Pollution Bulletin 44 : 211-216

van Franeker, J. A., Blaize, C., Danielsen, J., Fairclough, K., Gollan, J., Guse, N., Turner, D. M. 2011. Monitoring plastic ingestion by the northern fulmar Fulmarus glacialis in the North Sea. Environmental Pollution 159: 2609-2615.

van Sebille, E., C.Wilcox, L.Lebreton, N.Maximenko, D.Hardesty, J.van Franeker, M.Eriksen, D.Siegel, F.Galgani, K.Law, in press. Global Inventory of Small Floating Plastic Debris. Env. research letters.

Vegter, A.C., Barletta, M., Beck, C., Borrero, J., Burton, H., Campbell, M.L., Costa, M.F., Eriksen, M., Eriksson, C., Estrades, A., Gilardi, K.V.K., Hardesty, B.D., Sul, J.A.I. do, Lavers, J.L., Lazar, B., Lebreton, L., Nichols, W.J., Ribic, C.A., Ryan, P.G., Schuyler, Q.A., Smith, S.D.A., Takada, H., Townsend, K.A., Wabnitz, C.C.C., Wilcox, C., Young, L.C., Hamann, M., 2014. Global research priorities to mitigate plastic pollution impacts on marine wildlife. Endangered Species Research 25, 225-247. doi:10.3354/esr00623

Venables, W.N., Ripley, B.D., 2002. Modern Applied Statistics with S. Fourth Edition. Springer, New York. ISBN 0-387-95457-0

Wilcox, C., Hardesty, B. d., Sharples, R., Griffin, D. a., Lawson, T. j., Gunn, R., 2013. Ghostnet impacts on globally threatened turtles, a spatial risk analysis for northern Australia. Conservation Letters 6, 247-254. doi:10.1111/conl.12001

Wilcox, C., Sebille, E.V., Hardesty, B.D., 2015. Threat of plastic pollution to seabirds is global, 
pervasive, and increasing. PNAS 112, 11899-11904. doi:10.1073/pnas.1502108112

Witherington, B., Hirama,S., Hardy, R., 2012. Young sea turtles of the pelagic Sargassumdominated drift community: habitat use, population density, and threats. Marine Ecology Progress Series 463: 1-22.

Worton, B.J., 1989. Kernel methods for estimating the utilization distribution in home-range studies. Ecology 70: 164-168. 


\section{Figure 1}

Sampling plan of the aerial transects performed in the French Exclusive Economic zone and boundary waters in winter and summer 2011-2012 (from Pettex et al. 2014, courtesy of

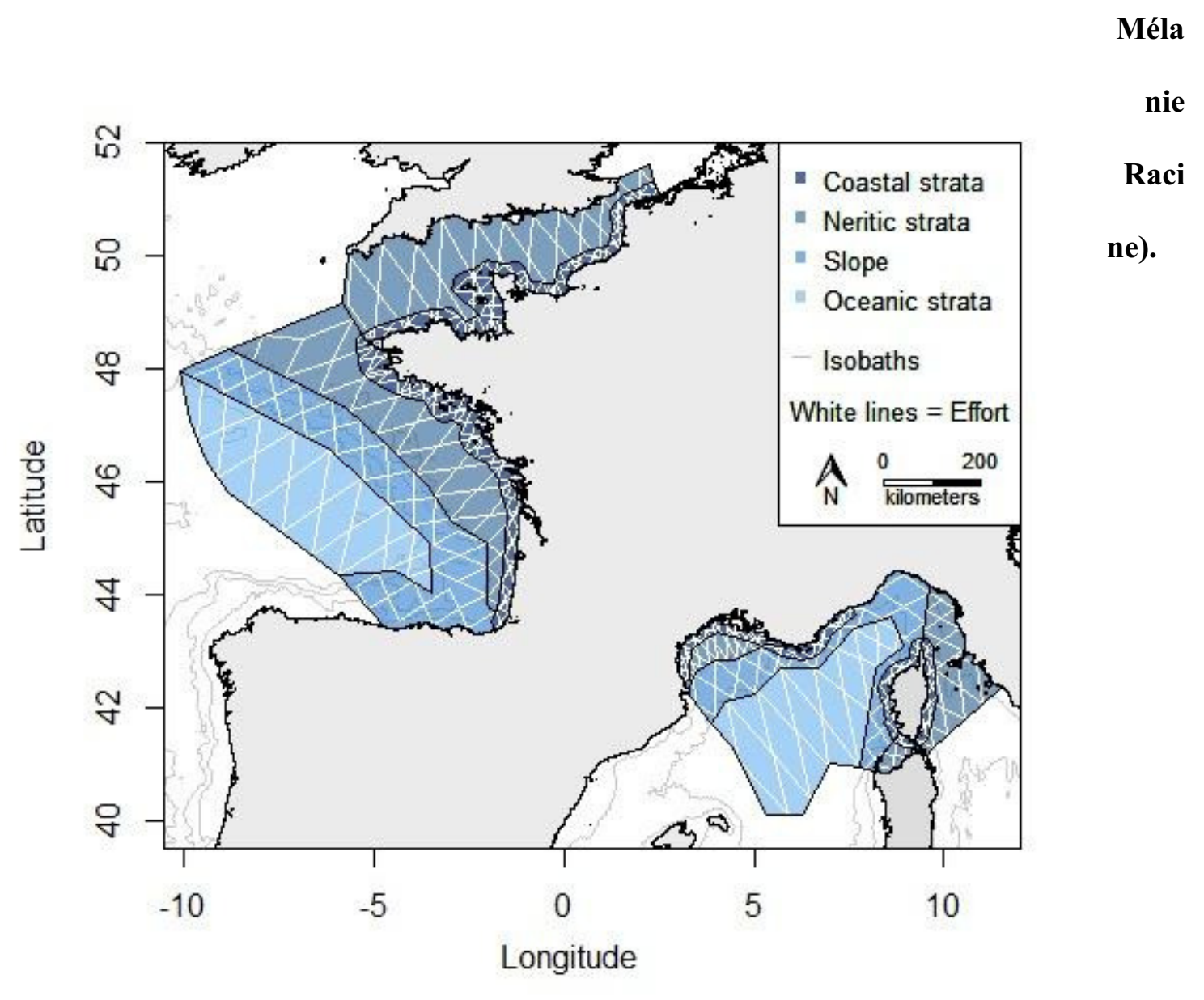




\section{Figure 2}

Kernel home range of marine debris (red) and sea turtles (green) : $95 \%$ (non filled dashed line), $50 \%$ (dashed line lightly filled), $10 \%$ (dashed line darkly filled); location coordinates in Lambert 93 (metres).
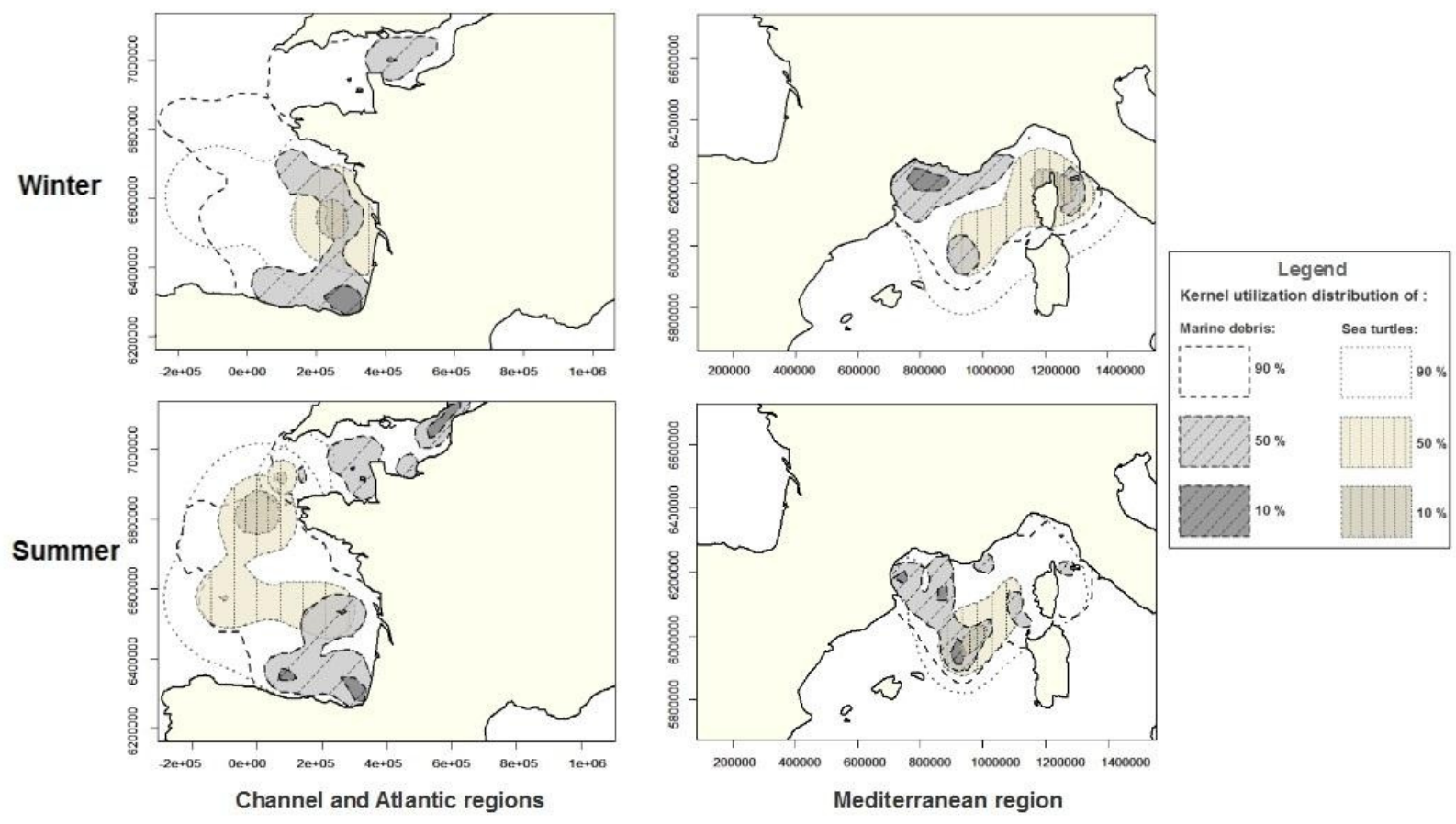


\section{Figure 3}

Observed exposure of sea turtles to debris in the 3 fronts of the metropolitan French waters in relation to the distance from the turtles (Top: Probability
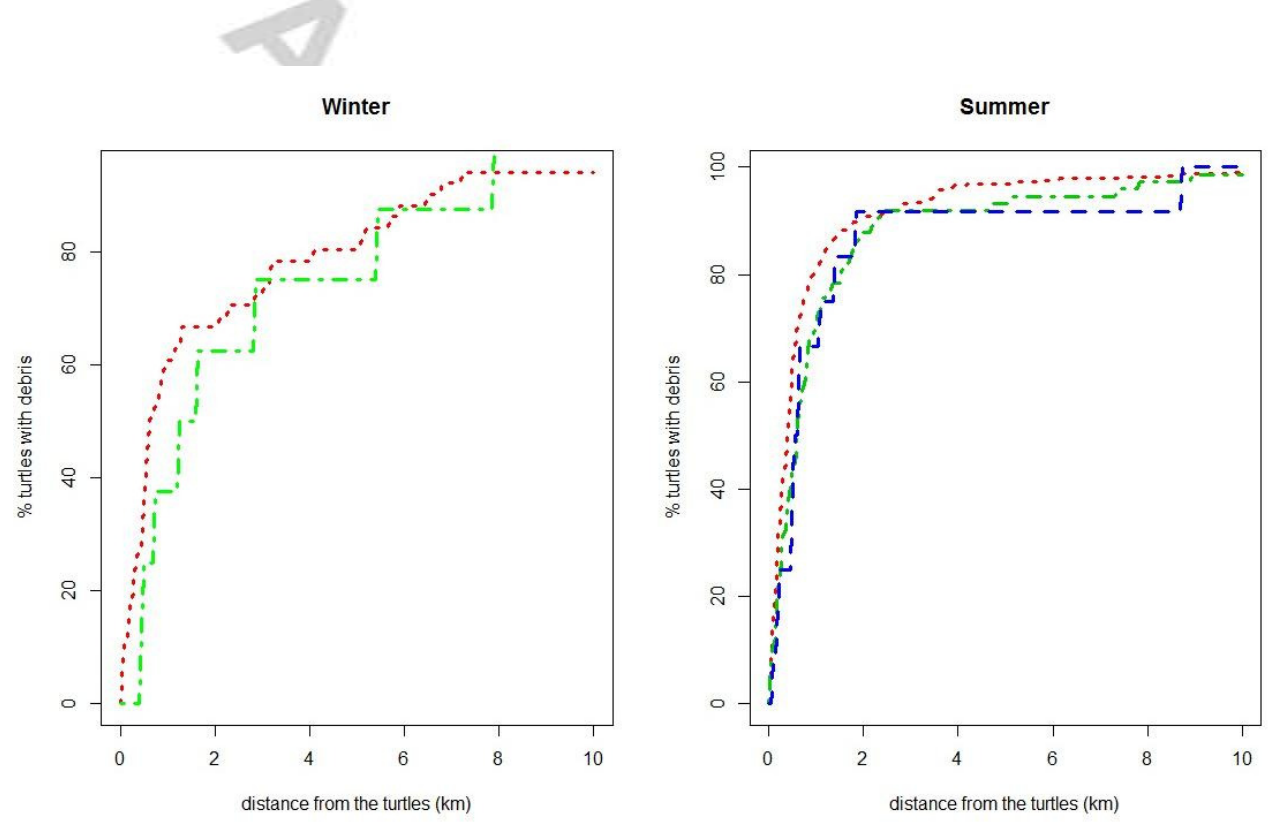

of turtles to be surrounded by debris; below : Mean number of surrounding debris per turtle and confidence interval)
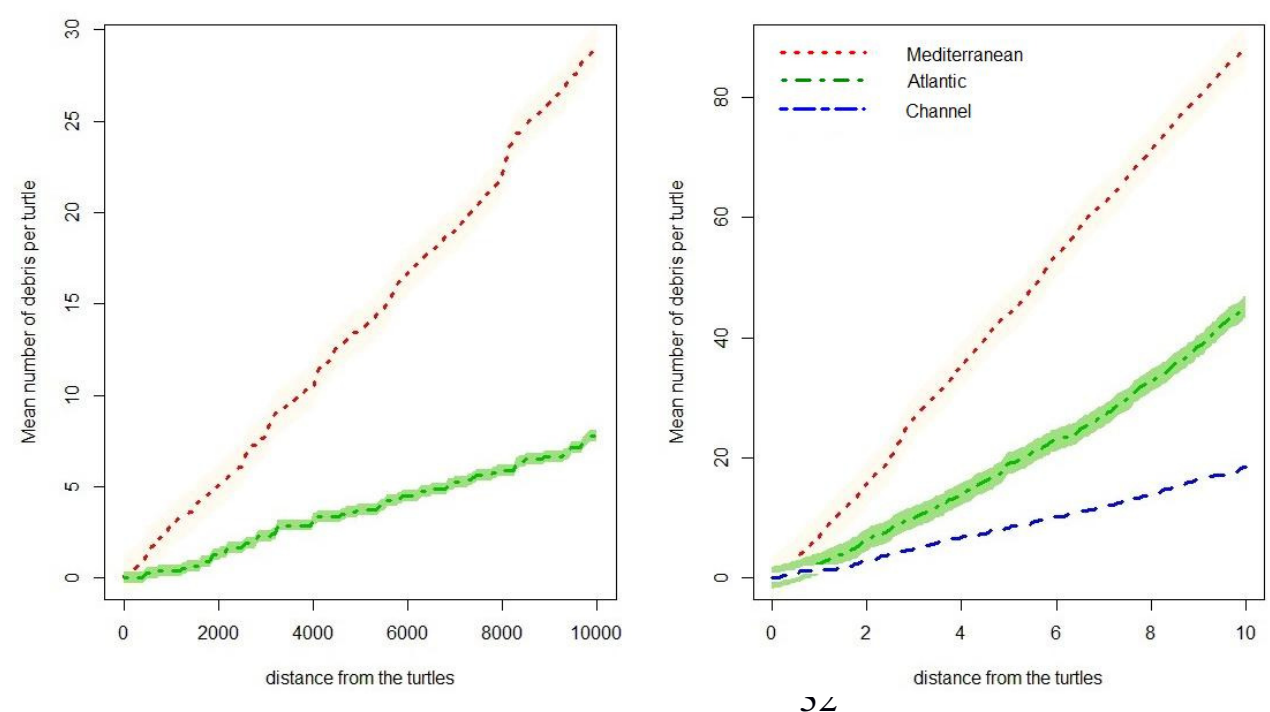


\section{Figure 4}

Mean observed number of debris per turtle (black line) compared to the mean number of randomized debris per turtle (dashed line, $95 \%$ confidence interval in grey) in relation to the distance from turtles, respectively (from left to right) in the Mediterranean region, the Atlantic region and the Channel region.
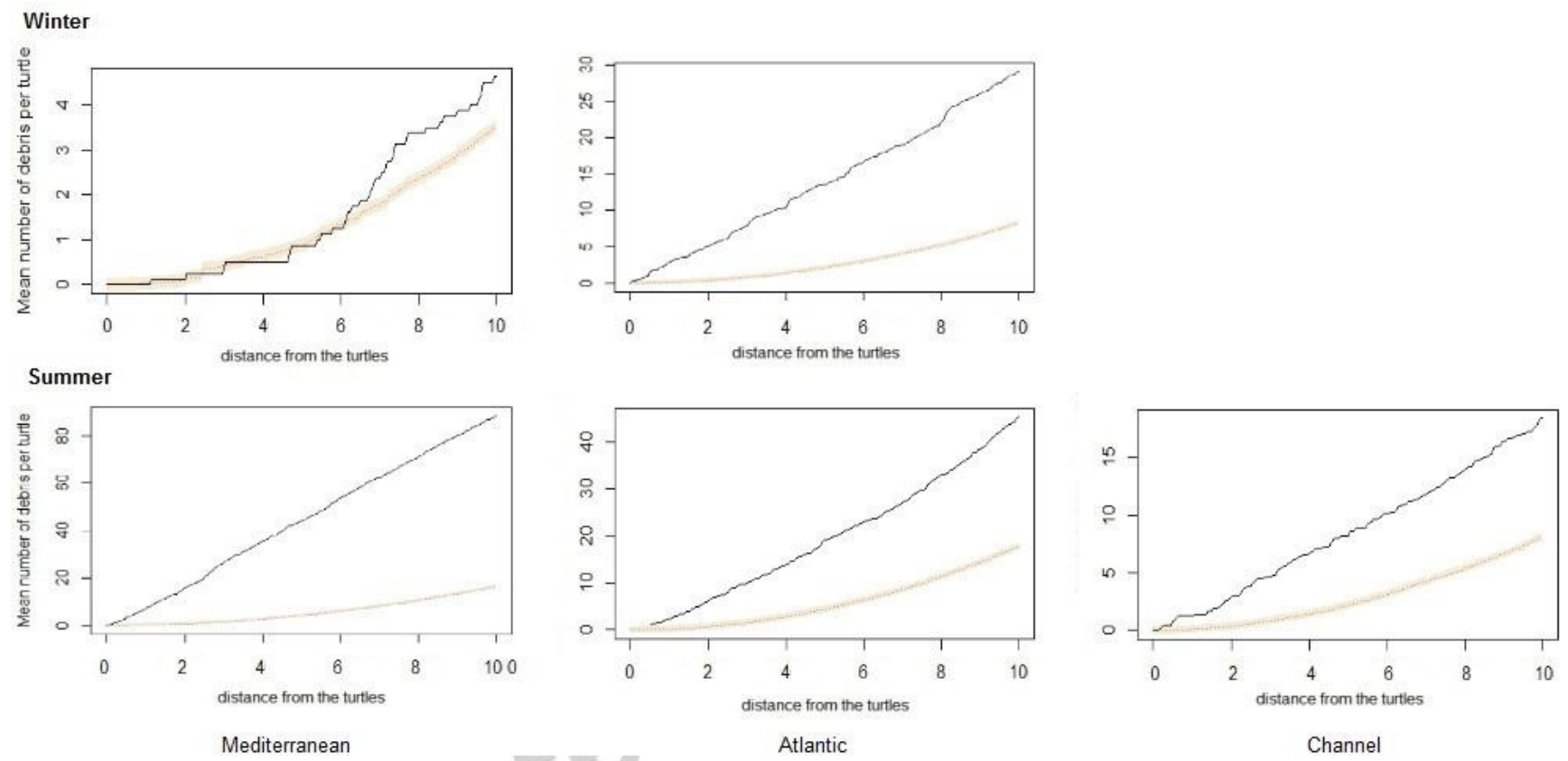

Mediterranean

Atlantic

Channel 


\section{Appendix 1}

Probability that the mean observed number of surrounding debris per turtle exceeds the mean number of randomized debris per turtle in relation to the distance from the turtles, respectively (from left to right) in the Mediterranean region, the Atlantic region and the Channel region.
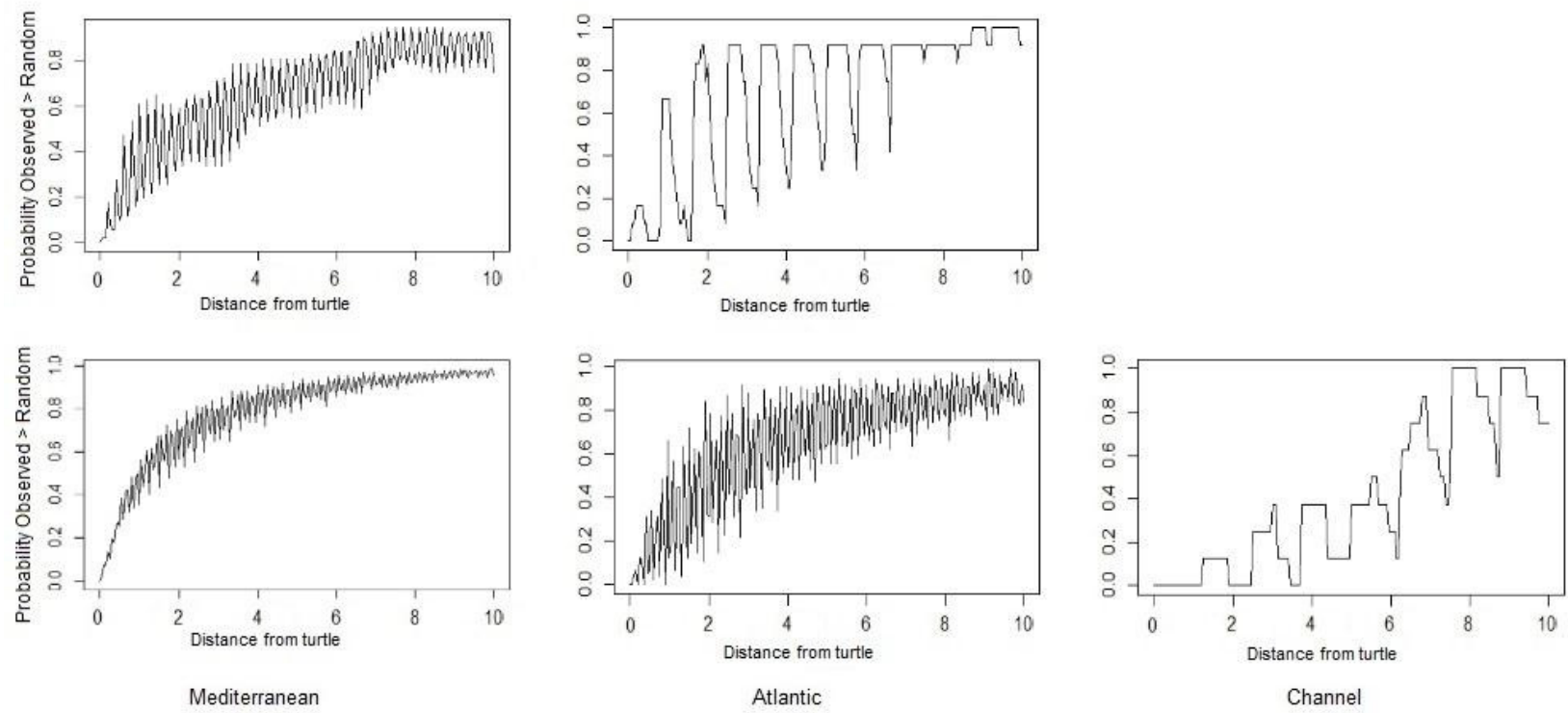


\section{Appendix 2}

Effect size (Cohen's d) measuring the difference between observed and theoretical mean number of surrounding debris per turtle in relation to the distance from the turtles, respectively (from left to right) in the Mediterranean region, the Atlantic region and the Channel region.
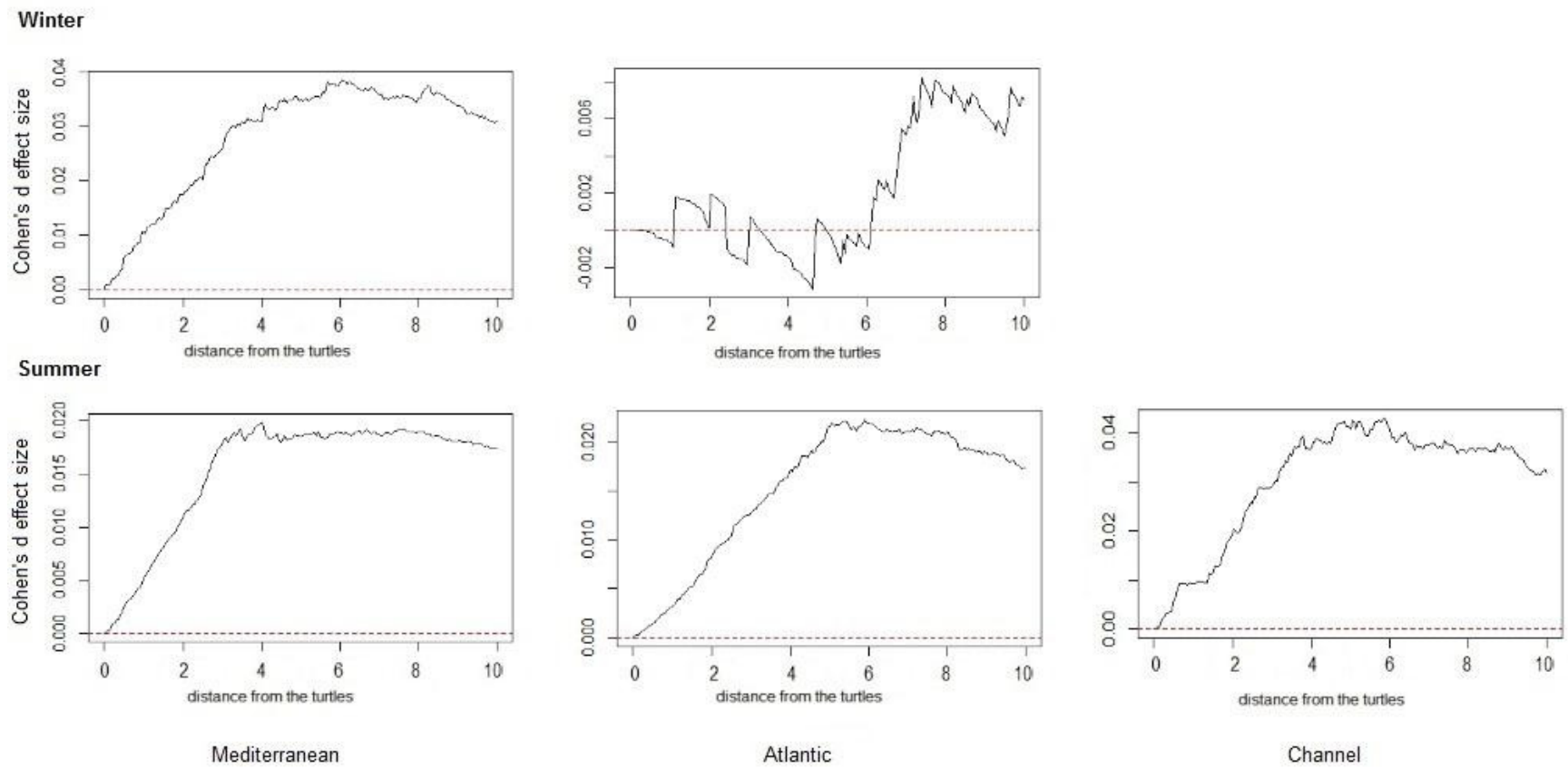


\section{Table 1}

Table 1 Summary of the data recorded from aerial SAMM survey campaigns in winter and summer 2011-2012: the number of locations (i.e., where turtles were observed), the mean group size (i.e., the mean number of individuals counted per location) and the total number of individuals counted across the region are presented per season for each of the three regions (the Channel region, the Atlantic and the Mediterranean regions).

\section{A. Sea turtle data}

(Abbreviations: Chelon. For Cheloniidae family and Dermoch. for the Dermochelyidae families)

\begin{tabular}{|c|c|c|c|c|c|c|c|c|c|c|c|}
\hline \multirow{2}{*}{ Region } & \multirow{2}{*}{ Season } & \multicolumn{3}{|c|}{ Number of recorded locations } & \multicolumn{4}{|c|}{ Mean group size per location $( \pm \mathrm{sd})$} & \multicolumn{3}{|c|}{ Total number of individuals } \\
\hline & & Chelon. & Dermoch. & Total & Chelon. & Dermoch. & Tot & Max & Chelon. & Dermoch. & Total \\
\hline \multirow{2}{*}{ Channel } & winter & 0 & 0 & 0 & 0 & 0 & 0 & 0 & 0 & 0 & 0 \\
\hline & summer & 0 & 12 & 12 & 5 & 1 & 1 & 1 & 0 & 12 & 12 \\
\hline \multirow{2}{*}{ Atlantic } & winter & 1 & 7 & 8 & 1 & 1 & 1 & 1 & 1 & 7 & 8 \\
\hline & summer & 6 & 68 & 74 & 1 & 1 & 1 & 1 & 6 & 68 & 74 \\
\hline \multirow{2}{*}{$\begin{array}{l}\text { Mediter } \\
\text { ranean }\end{array}$} & winter & 51 & 0 & 51 & 1 & 0 & 1 & 1 & 51 & 0 & 51 \\
\hline & summer & 324 & 0 & 324 & & 0 & $\begin{array}{l}1.02 \\
\pm 0.19\end{array}$ & 3 & 332 & 0 & 332 \\
\hline
\end{tabular}

\section{B. Marine debris data (Macrodebris ("Macro") and fishing debris ("Fishing")}

\begin{tabular}{|c|c|c|c|c|c|c|c|c|c|c|c|}
\hline \multirow[t]{2}{*}{ Region } & \multirow[t]{2}{*}{ Season } & \multicolumn{3}{|c|}{ Number of recorded locations } & \multicolumn{4}{|c|}{$\begin{array}{c}\text { Mean group size per location ( } \pm \text { sd; } \\
\max )\end{array}$} & \multicolumn{3}{|c|}{ Total number of items } \\
\hline & & Macro & Fishing & Tot & Macro & Fishing & Tot & Max & Macro & Fishing & Total \\
\hline Channe & winter & 842 & 68 & 910 & $1.8 \pm 9.23$ & 1.01 & 1.74 & 200 & 1,517 & 69 & 1,586 \\
\hline
\end{tabular}




\begin{tabular}{|c|c|c|c|c|c|c|c|c|c|c|c|}
\hline \multirow[t]{2}{*}{1} & & & & & 200 & $\pm 0.12 ; 2$ & \pm 8.878 & & & & \\
\hline & summer & 2806 & 116 & 2,922 & $\begin{array}{c}1.95 \pm 3.18 \\
50\end{array}$ & $\begin{array}{c}1.13 \\
\pm 0.86 ; 10\end{array}$ & $\begin{array}{r}1.92 \\
\pm 3.13\end{array}$ & 50 & 5,476 & 131 & 5,607 \\
\hline \multirow[t]{2}{*}{ Atlanti } & winter & 2744 & 146 & 2,890 & $\begin{array}{c}1.74 \pm 6.25 \\
200\end{array}$ & $\begin{array}{c}1.01 \\
\pm 0.12 ; 2\end{array}$ & $\begin{array}{c}1.7 \\
\pm 6.09\end{array}$ & 200 & 4,758 & 148 & 4,906 \\
\hline & summer & 9869 & 282 & 10,149 & $\begin{array}{c}2.26 \pm 3.92 \\
200\end{array}$ & $\begin{array}{c}1.04 \\
\pm 0.26 ; 4\end{array}$ & $\begin{array}{r}2.22 \\
\pm 3.87\end{array}$ & 200 & 22,293 & 293 & 22,586 \\
\hline \multirow{2}{*}{$\begin{array}{l}\text { Mediter } \\
\text { ranean }\end{array}$} & winter & 4050 & 41 & 4,091 & $\begin{array}{c}2.12 \pm 3.25 \\
50\end{array}$ & $\begin{array}{c}1.05 \\
\pm 0.31 ; 3\end{array}$ & $\begin{array}{l}2.11 \\
\pm 3.23\end{array}$ & 50 & 8,581 & 43 & 8,624 \\
\hline & summer & 6417 & 57 & 6,474 & $\begin{array}{c}2.56 \pm 6.9 \\
250\end{array}$ & $\begin{array}{c}1.05 \\
\pm 0.29 ; 3\end{array}$ & $\begin{array}{r}2.54 \\
\pm 6.87\end{array}$ & 250 & 16,421 & 60 & 16,481 \\
\hline
\end{tabular}




\section{Table 2.}

Sea turtle and marine debris density of distribution and exposure risks of sea turtles to marine debris evaluated per season (winter 2011 and summer 2012) for each of the three regions (the Channel, the Atlantic and the Mediterranean regions).

\begin{tabular}{|c|c|c|c|c|c|c|c|c|c|c|}
\hline \multirow{2}{*}{ Region } & \multirow{2}{*}{$\begin{array}{c}\text { Seaso } \\
\mathbf{n}\end{array}$} & \multicolumn{3}{|c|}{$\begin{array}{l}\text { Sea turtles spatial } \\
\text { distribution }\end{array}$} & \multicolumn{3}{|c|}{$\begin{array}{c}\text { Marine debris spatial } \\
\text { distribution }\end{array}$} & \multirow{2}{*}{$\begin{array}{c}\text { Probabili } \\
\text { ty debris } \\
\text { within } \\
\text { turtle } \\
95 \% \\
\text { Kernel }\end{array}$} & \multirow{2}{*}{\begin{tabular}{|c|} 
Probabilit \\
$y$ \\
individual \\
s be \\
surrounde \\
d by \\
debris in \\
a radius \\
of $2 \mathrm{~km}$
\end{tabular}} & \multirow{2}{*}{$\begin{array}{c}\text { Mean } \\
\text { number } \\
\text { of debris } \\
\text { per } \\
\text { individu } \\
\text { al in a } \\
\text { radius of } \\
2 \mathrm{~km}\end{array}$} \\
\hline & & $\begin{array}{c}h \text { value } \\
(\mathrm{m})\end{array}$ & \begin{tabular}{|c|} 
Kernel \\
$\mathbf{1 0 \%}$ \\
$\left(\mathbf{k m}^{2}\right)$ \\
\end{tabular} & $\begin{array}{c}\text { Kernel } \\
95 \% \\
\left(\mathbf{k m}^{2}\right)\end{array}$ & $\begin{array}{l}h \text { value } \\
(\mathrm{m})\end{array}$ & $\begin{array}{c}\text { Kernel } \\
10 \% \\
\left(\mathrm{~km}^{2}\right) \\
\end{array}$ & \begin{tabular}{|c|} 
Kernel \\
$95 \%$ \\
$\left(\mathbf{k m}^{2}\right)$
\end{tabular} & & & \\
\hline \multirow{2}{*}{ Channel } & winter & I & I & I & $\begin{array}{c}29,564.7 \\
6\end{array}$ & 919.65 & $\begin{array}{c}119,554.8 \\
5\end{array}$ & I & I & I \\
\hline & $\begin{array}{c}\text { summe } \\
\mathrm{r}\end{array}$ & $\begin{array}{c}27009.8 \\
8\end{array}$ & 849.37 & $36,225.51$ & $\begin{array}{c}30,244.7 \\
1\end{array}$ & $\begin{array}{c}6442.2 \\
2\end{array}$ & $137,127.4$ & 0.93 & 91.67 & $\begin{aligned} & 2.92 \\
\pm & 2.19\end{aligned}$ \\
\hline \multirow{2}{*}{ Atlantic } & winter & $\begin{array}{c}81985.5 \\
1\end{array}$ & $\begin{array}{c}8,510.3 \\
8\end{array}$ & $\begin{array}{c}284,847.2 \\
8\end{array}$ & $\begin{array}{c}37,520.0 \\
2\end{array}$ & $\begin{array}{c}8,123.2 \\
6\end{array}$ & $\begin{array}{c}282,283.1 \\
7\end{array}$ & 0.7 & 62.65 & $\begin{array}{l}0.12 \\
\pm 0.35\end{array}$ \\
\hline & $\begin{array}{c}\text { summe } \\
\mathrm{r}\end{array}$ & 72313.5 & $\begin{array}{c}16,781 \\
7\end{array}$ & $\begin{array}{c}383,019.8 \\
3\end{array}$ & $\begin{array}{c}28,140.5 \\
1\end{array}$ & $\begin{array}{c}8,227.9 \\
5\end{array}$ & $\begin{array}{c}256,094.8 \\
2\end{array}$ & 0.71 & 87.83 & $\begin{array}{l}\quad 6.27 \\
\pm 8.08\end{array}$ \\
\hline \multirow{2}{*}{$\begin{array}{l}\text { Mediterrane } \\
\text { an }\end{array}$} & winter & $\begin{array}{c}70,593.0 \\
1 \\
\end{array}$ & 13,584 & $316,611.7$ & $\begin{array}{c}32,475.8 \\
4\end{array}$ & \begin{tabular}{|c}
$7,812.4$ \\
6 \\
\end{tabular} & $\begin{array}{c}222,097.1 \\
4\end{array}$ & 0.71 & 66.67 & $\begin{array}{r}5.04 \\
\pm 8.48 \\
\end{array}$ \\
\hline & $\underset{r}{\operatorname{summe}}$ & $\begin{array}{c}42,964.2 \\
2\end{array}$ & $\begin{array}{c}5,512.7 \\
6\end{array}$ & $\begin{array}{c}212,241.3 \\
8\end{array}$ & $\begin{array}{c}27,819.3 \\
6\end{array}$ & $7,853.4$ & $\begin{array}{c}208,676.0 \\
1\end{array}$ & 0.89 & 90.43 & $\begin{aligned} & 15.68 \\
\pm & 27.43\end{aligned}$ \\
\hline
\end{tabular}

